This item was submitted to Loughborough's Research Repository by the author.

Items in Figshare are protected by copyright, with all rights reserved, unless otherwise indicated.

\title{
Crime, labour and the wisdom of Solomon
}

PLEASE CITE THE PUBLISHED VERSION

\section{LICENCE}

CC BY-NC-ND 4.0

\section{REPOSITORY RECORD}

Pease, Ken. 2019. "Crime, Labour and the Wisdom of Solomon”. figshare. https://hdl.handle.net/2134/935. 


\title{
Crime, Labour and the Wisdom Of Solomon
}

\author{
KEN PEASE
}

ABSTRACT The most fundamental fact about crime is that its incidence is largely determined by factors outside the criminal justice process - by the design, use and maintenance of artefacts and of social arrangements, and by the socialisation of people. Labour will make a difference insofar as it acts according to that reality, by changing organisational structure within the Home Office, and by directly and indirectly seeking to influence the real engines of crime. There is a useful parallel in the policy thrust towards environmental sustainability. The greening of policy proceeds (too slowly) through the policy of inducing industry, commerce and citizens to behave differently, by penalising the un-green, rewarding the green, and most centrally by establishing sustainability as a criterion of good practice about which Government cares. The greening of policy is under way. The remoralisation of policy as suggested here is not. While crime control is ghettoised in the Home Office and entwined with blame allocation, retribution and equally the more gentle aspirations of rehabilitation and reintegration, it will remain wrongly directed and incapable of full success.

It will be recalled that Solomon gained his reputation for wisdom (I Kings 4) when custody of a baby was in contention between two women. He asked for a sword to divide the baby equally. One woman thereupon relinquished her claim. Solomon concluded that the woman who was prepared to relinquish her claim for the baby's sake was the real mother. Solomon's wisdom therefore consists of going directly to the motivation to act, rather than the specifics of action. That is a lesson which could with profit be learned by crime prevention practitioners. The engines of crime lie in our chosen physical and social arrangements. These are manipulable. The greatest difference which Labour could make is as mundane as it is important, namely to recognise that simple fact, and to recognise its consequences: to sever crime control policy from the actions of the criminal justice process as completely as possible, and to facilitate crime control by incentivising it. There is a useful parallel in the policy thrust towards environmental sustainability. The greening of policy proceeds (too slowly) through the policy of inducing industry, commerce and citizens to behave differently, by penalising the un-green, rewarding the green, and most centrally by establishing sustainability as a criterion of good practice about which Government cares. The greening of policy is under way. The remoralisation of policy as suggested here is not. While crime control is ghettoised in the Home Office and entwined with blame allocation, retribution and equally the more gentle aspirations of rehabilitation and reintegration, it will remain wrongly directed and incapable of full success. Proactive policing and the targeting of prolific offenders will make a substantial difference, but a society whose products and services do not invite crime will both make a difference in their own right and facilitate action against the determinedly criminal. As Inspector Maurice Winning said of the conviction of a prolific offender, "Crime levels are so

Ken Pease, Professor of Criminology, School of Human and Hcalth Sciences, University of Huddersficld, Queensgate, Huddersfield HDl 3DH, UK. Tel/Fax: 01484682799. 
low in that area of Newcastle that it is easy to target people when a string of offences are committed" (Daily Mirror, 17 February 1998, p. 7).

To change Testaments from the Solomon story, but continue the Biblical theme, my Road to Damascus was the M62 as I drove home from what was then Wetherby Borstal (although fortunately for me and the other road-users, and unlike St. Paul, the experience did not render me blind). It was the day (in 1981?) when new 'strict regime' detention centres were opened at New Hall and Send, which fact was duly reported on the news on my car radio. The next item was the record profits made that year by Ford. The link was that many of those who would be detained in those centres would have stolen cars. The cars they would disproportionately have taken were Ford Cortinas. The reason was that these cars combined good performance with execrable perimeter security. The company's choice to make savings on security contributed to Ford's record profits.

All physical and social innovations go through three phases:

1. innovation with indifference to crime consequences;

2. crime harvests as a consequence of 1 ;

3 . the retrofitting of partial solutions to 2 .

Paul Ekblom (personal communication) has many examples of this, for example the introduction of smooth-edged coins, followed by coin clipping and then the introduction of milled edges. A recent example of the cycle is the proliferation of high value, small volume, anonymous communication devices easily convertible to criminal use. I speak of mobile phones. Many aspects of their manufacture, distribution and call patterns could have been used to limit their utility as stolen goods or tools in drug sales. Some of these measures are now being belatedly taken (see Roberts, 1996).

Taking one instance from the near future, the advent of digital TV will generate a burglary bonanza. There will be two phases. From now to 2009 set-top boxes will be useable with analogue TV. Thereafter integrated digital TV will take over and all analogue TVs will be useless. From 2000, there will become available integrated digital TVs with high value and increasingly greater portability. By 2010 or soon thereafter, some $15-20$ million of these will be in UK homes. Burglary has historically involved theft of TV in between one-fifth and one-third of cases, on the various sweeps of the British Crime Survey (21\% in 1995). It takes little imagination to envisage what will happen to burglary when the new equipment becomes necessary for televiewing, and becomes so over a short period.

If security of digital TV is taken seriously now, this need not happen. Digital TVs have a uniquely identifiable microprocessor which can be interrogated remotely. Stolen TVs can thus be electronically deactivated, for example by using a Ceefax page containing the numbers of stolen TVs which is scanned automatically at switch-on. If a TV finds its own number, it switches itself off, and remains unusable until it is restored to its owner and the number removed from the Ceefax page. This can be done at trivial cost, being a software solution. What is necessary is the motive of manufacturers to do this. Some companies (notably Aiwa and Sharp) are moving in this direction, but Home Office, police and insurer pressure seems necessary to motivate suppliers and retailers to make it universal, and consumers to wish it to be so. ${ }^{1}$

In general:

1. The crime we suffer is a cost we (Ford Motor Company, each householder and place of work, and the rest) incur by our choice of social and physical arrangements.

2. These arrangements are not under the control of the Home Office.

3. Many means of crime control are to hand. It is the motive to deploy them which is lacking. 
The first two numbered statements would gain assent from all informed commentators on crime. As to attempts to remedy crime problems, they would disagree about the relative emphasis to be placed on changes to long-run (education, product design, etc.) ${ }^{2}$ and short-run (situational prevention, housing allocation, etc.) arrangements. The third numbered statement would gain less agreement. This is odd, because it requires only belief in the first statement supplemented by the conviction that social and physical arrangements are manipulable.

The third statement is the key to the rational allocation of expenditure to reduce crime. This paper will not be about particular crime prevention methods. It is about the deployment of motives and the design of structures that reflect these motives. It will discuss what is wrong with criminology and criminal policy as crime reduction tools. Thereafter some recommendations will be made about the redesign of the discipline and the policy to facilitate crime reduction. Because this paper is about motives rather than a particular programme of change, it is not appropriate to assign effect sizes, costs and benefits. What is proposed is not a particular programme, but an enterprise whose purpose is the incentivisation of crime prevention, in particular future crime patterns.

\section{Policy As Incentive Manipulation}

Government is substantially about changing incentives operating on people, or which people perceive to be operating on them. In recent months, hard incentives towards less use of private cars have been applied, such as the undertaking to increase fuel prices annually by $6 \%$ above inflation. Soft incentives seem also to have become relevant, with both major motoring organisations making pronouncements about the non-sustainability of increasing road use.

The self-evident reason for operating at the level of incentive or disincentive rather than prescribing action is that the motivated person may achieve desired ends in a variety of ways. Legislating particular behaviour (e.g., a ban on cars of more than $1500 \mathrm{cc}$ ) would restrict freedom to choose the means to economise in ways which could more easily be subverted (e.g., a reversion to rotary engines, with smaller capacity but lower fuel-efficiency). Increasing fuel prices may lead people to use public transport more, share cars more, buy smaller or more fuel-efficient cars, or all of these. The choice is the one most consistent with their wishes and lifestyle.

While the manipulation of tax, benefits, opportunities and their regulation are elsewhere the stuff of policy, this is not the case as regards crime. The literature of crime prevention is primarily about what should be done assuming the intention to prevent crime, rather than manipulating that intent. There are some honourable exceptions, the British ones including work by Field \& Hope (1990), and by Laycock \& Tilley (1995). However, in general there are large literatures about what to do given that you want to prevent crime; but precious little about how to stimulate that wish into existence.

When people want, or are induced to want, to reduce crime, they seem largely to do so without much difficulty and often without much recourse to criminology. HMV successfully reduced its Oxford Street crime experience when the threat of diminution of police services was made (see Ekblom, 1986). The Department of Social Security did its own thing when it recognised the scale of benefit fraud and how that translated into the scope for reductions in income tax. The UK plastic card industry (collaborating through the Association for Payment and Clearment Services (APACS) organisation) took effective steps to reduce fraud levels (see Levi $e t$ al., 1991, for the report on which the initiative was based).

Why does the normal emphasis of policy development on manipulating motives not apply to potential victims of crime? Arguably, it is because the Department of State seen to be responsible for crime issues is the Home Office, and the nature of that responsibility is blame allocation and offender processing, rather than the manipulation of the motive to reduce 


\section{Ken Pease}

In consequence, crime reduction is marginalised in both criminological and policy discourse. This is reflected in sponsorship arrangements that emphasise the rhetoric of crime control at the expense of local effectiveness. Finally, criminology has typically not been future-oriented, favouring analysis in hindsight over the riskier business of prediction. For all these reasons, it is no surprise that almost uniquely among Government Departments, the Home Office has presided over an almost unremitting worsening of the problem which it was established to address. These points will be discussed in a little more detail, before the recommendations which flow from them are developed.

\section{Problem 1: Blame Allocation Rules, OK?}

In a prescient paper in 1973 entitled 'Crime and Criminal Justice at the Turn of the Century', Leslie Wilkins was gloomy. He wrote:

There has been little development of technology which makes crime more difficult; technocrime. The outcome has been the neglect of human purpose in criminology and crime policy. iques have been concerned with the various aspects of the finding of guilt and the allocation of blame. Fingerprints, voiceprints, lie-detectors and the like help only in pinning the blame the more certainly on the person who has already been suspected. Even the modus operandi index is used to identify persons who may have committed the crime, rather than for the purposes of preventing further crimes of a similar nature. (p. 22)

In conversation, Leslie Wilkins frequently contrasts his experience in the prevention of aircraft accidents with the central theme of criminal policy, namely blame allocation. He advocated an approach to crime derived from operational research, wherein all systems involved in an accident or near accident are considered, so that system redesign made recurrence unlikely or impossible. Leslie may be forgiven for having returned to the issue periodically ever since, because however much people may nod when he says it, they do not behave as if it were true.

\section{Problem 2: the Neglect of Human Purpose in Criminology}

When I was a psychology student, I came across a neat study showing the limitations of behaviourism. A person's hand was strapped to a level surface, palm down, with only the index finger free to move. Under the index finger was a metal plate through which a painful current could be run. A bell warned of the advent of current. Very soon, the index finger was being raised in response to the bell and before the shock. Next, the hand was turned over, and restrapped, this time with palm up. What did the index finger do in response to the bell? It moved upwards. So the response was the opposite one at the muscular level, but the same one at the level of purpose.

What is crime control policy and practice like? Too often, it seems like a person who when their hand is turned over on an electrified surface, would respond to the warning bell by pressing the hand down into the plate. What justifies this view?

\section{Problem 3: Marginalising Crime Control}

One Huddersfield incident puzzled me. While British Telecom (BT) was offering support for our work on repeat victimisation and inviting us to talk about it at national Neighbourhood Watch conferences which it sponsored, one of the chronically victimised sites in the town was the British Telecom vehicle compound. Our police colleagues ended up installing video equipment in the compound (which yielded detections). BT did not install its own additional protections. Thus BT was prepared to sponsor criminological research and the Neighbour- 
hood Watch movement generally, but was not motivated to protect itself against its own repeated crime victimisation. What sense does that make? It is easy to see how an individual or organisation might make a rational economic decision not to protect itself against crime. It is less obvious why this should happen alongside sponsorship of crime control efforts. The account that follows is probably far too cynical.

The sponsorship of crime control efforts has direct and indirect advantages. The direct benefits include the public relations boon of being seen to assume the moral high ground, and the subtle indebtedness incurred by the police service. The indirect benefit is that, being seen as part of the solution, one is not seen as part of the problem. Put crudely, the public and private sponsorship of academic criminology serves to distance crime control from the policy heartland. Widely different traditions suggest that we should look for the causes of crime in social and physical arrangements. Simon Field's and other work on the crime concomitants of economic conditions (see Council of Europe, 1995) represents one such approach. Marcus Felson's (1994) counting of things stealable is another. (In passing, his VIVA model, which identifies stealability in terms of Value, Inertia, Volume and Access, and considers trajectories in these terms through which objects pass over time, is a wonderful heuristic device.)

In short, sponsorship serves many purposes. Among them it serves to locate crime control issues anywhere but with the sponsor. We have learned to be sceptical of press conferences in which relatives of murder victims appeal for help in detecting the murderer, only for those same relatives to be later identified as perpetrators of the crime. The British Retail Consortium will not imminently be sponsoring research about the ways in which its business practices are criminogenic.

The nature of the ghetto into which crime prevention is driven by sponsorship differs according to the sponsor. Home Office and private sector support makes the ghetto one in which you address the specifics of crime circumstance and crime processing rather than the engines of crime reduction. Economic and Social Research Council and related funding makes the ghetto one of the sociology of deviance, with its impenetrable prose, overt politicisation and apparent indifference to questions of application.

Other developments serve to keep the explosion and practice of crime control safely marginalised. One of these is the absolute rejection of victim blame. Victim blame applied to a person who suffers attack while walking home alone is inappropriate. Victim blame applied to BT's disinclination to protect its vehicle compound after repeated burglary may not be.

\section{Problem 4: Criminology as History}

All data are historical, but the future is where we have to live the rest of our lives. Criminology has largely neglected the challenge to extrapolate. Future-oriented books are rare, and largely blame-oriented (Olander \& Greenberg, 1977) or banal (Muraskin \& Roberts, 1996). It does not much matter for practical purposes whether prediction is good or poor. In fact the best predictions are self-defeating, in that people take steps to avoid the predicted future. It does matter that we should not continue to think of the ways of controlling yesterday's crime problems, like World War I generals fighting according to the tactics appropriate to the last war but one.

\section{So What?}

How would we behave if we were serious about crime control as distinct from blame allocation? Criminology is not well structured to address this question, still less inclined to regard it as central. It is instructive that the chapter on crime prevention in the second edition of the Oxford Handbook of Criminology (Maguire et al., 1997) is located in Part IV, 'Criminal 
Justice Structures and Processes' and apart from 'Social Dimensions of Crime and Justice' and 'Forms of Crime and Criminality'. The crime prevention function of the Home Office's Research and Statistics Directorate is located in its 'Offenders And Corrections' section. There could be few clearer demonstrations of the consideration of crime control separate from the engines of crime.

The problems identified in the paper to this point were:

1. The centrality of blame allocation rather than crime control in applied criminological discourse;

2. The too-easy taking for granted of the wish to reduce crime among individuals and organisations;

3. The way in which funding of crime control research tends to factor out the role of the funders as part of the problem; and

4. The timidity and/or lack of imagination amongst criminologists in making predictions plausible enough to alert those positioned to address emerging problems to do so.

In what follows, suggestions are made that are intended to be seen as relevant to the problems identified and where effort may profitably be located. They are couched in concrete terms in an attempt to be at least clear.

\section{Suggestions}

Within the Home Office

1. Grime reduction should be given a Research and Statistics Directorate existence outside Offenders and Corrections.

2. A Unit to anticipate emerging crime patterns and opportunities should be established involving the trawling of British Crime Survey data, Police Scientific Development Branch awareness of non-linear technological change, and Research and Statistics Directorate/Police Research Group expertise on policing and police data. This Unit would also seek to persuade the Economic and Social Research Council to mount a research programme on crime futures, and maintain close links with the Department of Trade and Industry Technology Foresight Programme, which has hitherto neglected crime control ramifications of changes it anticipates.

\section{Cross-departmental Work}

3. There should be a review of incentives operating upon citizens and organisations (including the police) in determining rational self-interest in crime reduction. It should be a TreasuryHome Office collaboration, and Simon Field's group within the Home Office Research and Statistics Department would be the obvious starting point for it. It would make recommendations for national and local taxation, from VAT rates on the home security devices to (possibly) levies on home insurance premiums to enable local communication systems to be installed giving citizens (say) phone information about recent crimes.

Tim Hope (1995) has identified four circumstances under which individual citizens would not involve themselves in crime-reduction efforts:

- when the perceived risk or costs of voluntary participation outweigh its apparent benefits;

- when neighbourhood commitment has opportunity costs - for example distracting from effort that might otherwise be spent in accumulating money to allow a move from the area; 
- when marginal additions in participation are perceived not to produce commensurate reductions in risk;

- when a critical mass of other citizens has been reached which allows the individual to become a 'free rider', enjoying the benefits of collective action without contributing to it.

To these may be added organisational factors leading to bodies not involving themselves in crime reduction. These include situations:

- where the departmental units would not themselves benefit from their crime-cutting achievements;

- where crime losses as a percentage of turnover does not reach a threshold at which it is deemed worthy of action. For the police, the proper unit of count is the event, but for business, the unit of count is currency.

I am no economist, and my understanding of how fiscal incentives work is naïve. Further, I recognise the complications. For instance, one wants to encourage people and businesses to stay in and move to high crime areas to make them more stable. So simple rebates to people and business who are not victimised is too simple. However, I know that behaviour is shaped by its consequences, and crime preventive behaviour is no exception. There are enough examples where action to reduce crime is penalised. These include:

- increased local taxation of shops after security enhancement which increases the shop's value;

- the Driver Vehicle and Licensing Authority (DVLA) is in a powerful position to organise vehicle licensing in ways less prone to crime than is now the case. Until recently its procedures almost invited fraud. There have been improvements but the central problem is that DVLA income is unaffected by fraud levels, so there is no continuing incentive to reduce those levels;

- local authority departments which operate within departmental priorities, disinclined to change expenditure patters which will benefit other departments. The problem is both illustrated and overcome in one authority by Bridgeman (1996);

- insurance lowers the optimum level of protections. In the present commercial climate it is possible (at least in the medium term) to ally low security with insurance protections.

It is crucial not to exclude the police from the process of incentivisation. Too many times have police officers said to me that crime prevention may put them out of a job. This is a joke with an unjokey centre. Police priorities will follow performance indicators and charter standards. If these standards do not make crime reduction central, there is no pivotal police motive to reduce crime.

4. The Ministerial group on crime prevention should be reconvened, with a Treasury minister chairing the group. Willingness to behave in crime reducing ways should be one factor in Treasury thinking in regulating Government expenditure. For example, Department of Transport willingness to shape vehicle identification and registration procedures in ways which save police time and hence Home Office expenditure should be made more transparent.

5. Nearly 20 years ago I suggested an annual crime and justice debate along the lines of the budget debate (Pease, 1979). Almost uniquely among things that I believed 20 years ago, I still believe that to be a good idea. Its primary purpose would be to see a much wider range of activities as crime relevant than has hitherto been the case. The point is that there is currently no political forum in which options are presented which go beyond the limited ones about offender processing. There should be a forum - both locally and nationally - in which, for 
example, the use of licensing laws, glass design, opening hours, taxi provision, publican training, drink advertising, proof of age, bar layout and food availability are all considered together as proximal crime circumstances. There is no suggestion that a raft of criminological research would be necessary before the debate could be sensible. A lack of a research base has not stopped the mixture of sense, dottiness and irrelevance in other debates. The purpose in advocating the process is not the direct achievement of an optimal solution, but the recognition that crime is driven by many things, and an all systems involved approach is necessary (see Wilkins, 1973).

\section{Soft Incentives}

Generally, there seems a disinclination to acknowledge the effect of soft incentives on action. In a rigorous and impressive series of studies, Opp $(1986,1989,1994 a, b)$ examines the roles of such incentives, (including intrinsic pleasure, expectations of reference persons, and the expectation of influence) in participation in political protests in East Germany before the revolution and the anti-nuclear movement. He further develops theory relevant to his work. In essence, he identifies powerful contributions made by a range of soft incentives, alone and in interaction. We would be unwise to neglect the role of soft incentives in stimulating crime control measures into existence.

Talk to the executives of APACS, and they will tell you that their drive to reduce plastic card fraud came before they decmed it commercially rational to do so, as a result of pressure from politicians. The Swedish security printers Stralfors were induced by the Swedish government to introduce laminated, controlled supply number plates with bar-coded car details, which ensure that the registration number does belong to the car on which it is placed. The motor industry in the UK acknowledges that it was the personal approach of the Home Secretary Baker that drove them to improve security on new cars (Peter Bachclor, Vauxhall, personal communication; see also Houghton, 1992, for the weapon which Baker used to get the attention of the car manufacturers). The specific suggestions which stem from the acknowledgement of the importance of soft incentives are as follows:

6. Parallel to the Queen's Award for Industry, institute the Princess Royal's Award for crime control. They would colloquially be known as Annies. They would offer a high profile inducement to reduce crime in circumstances which would otherwise be marginal. (This idea was conceived jointly with the journalist Nick Ross, who has consistently been a most stimulating and energetic colleague in proselytising crime control).

7. Routinise police (or Home Office) collection of data that suggest inter-organisational differences in rates of crime which should (?) be similar. For example, recent work (Matthews et al., 1998) suggests large differences between banks in rates of repeat robbery. This implies that some banks are putting into place measures after one robbery which prevents the next. Similar differences exist between car models (Houghton, 1992) and no doubt other products or services. Current work suggests large differences between estate agents in the rate at which homes on their lists are burgled. The suggestion is that such differences are made public if prior discussion fails to produce agreement to adopt best practice in repeat prevention (perhaps this is not such a soft incentive - perhaps it is softness with a hard edge!).

\section{Attack Testing as Routine}

As rehearsed earlier, our world innovates first and thinks of crime consequences later. A graphic (and wholly unconscious) example of this is provided by Bill Gates' description of the history and future of the computer (see Gates, 1995). We wish to move from this position 
to one in which crime consequences are anticipated and counter-moves incorporated at the point of innovation. There is no reason why this should slow the pace of innovation. It should simply extend the product usefulness of version 1.0 of a new degree or service. We would wish to have crime consequences addressable in Computer Aided Design (CAD) packages; among the criteria for Design Council and Royal Society of Arts awards; and to have routine attack testing of new products. Paul Ekblom has produced a superb framework for crime preventive design (Ekblom, 1997). It emphasises the evolutionary nature of crime and responses to it, and design tactics and strategy. There is nothing like it in terms of thinking sequences and countermoves. I would argue that this should be enriched and developed in two ways:

8. By sending it under a Ministerial letter to all University design departments, and to other design-relevant bodies, like the Design Council and the Royal Society of Arts, inviting comments and practical examples (and counter-examples) of its points.

9. To incorporate a national attack testing facility, and to devolve, perhaps to local authority weights and measures/trading standards departments, the responsibility for attack testing of new local products and services at the earliest possible stage of development. One can even imagine bolt-ons to CAD packages which automate this process. Thus the results of anticipatory attack testing would be available at the point at which change is still possible. One can imagine an appropriate logo (the Honesty flower?) being attached to all products thus assessed. (I admit a personal agenda here. I fear that a community safety function in local authorities will be seen as exclusively one for youth and social service staff. Weights and measures is the local authority department with a tradition closest to situational crime prevention, and merits a role in community safety. A local attack testing function would give it that role).

\section{Reclaiming The Future}

Perhaps the single most central task is to think of the future as different from the past. Ekblom (1997) identifies some of the ways in which it will be so. Sutton \& Mann (1998) have innovated research into the criminological implications of the Net. Ways in which change will be non-linear include:

- the growth of e-commerce and its problems for security of payment systems (Schwartz, 1997);

- the globalisation of financial systems and its threat to national tax revenues (Platt, 1997);

- the availability of music and text via the Net and the copyright implications of that (Browning, 1997);

- the role of the Internet in political terrorism/activism (Bennahum, 1997) and the scope for electronic warfare (Craddock, 1997). It is of no little interest that many of the first generation of computer viruses originated in Bulgaria.

The implications of the Net for a sense of place are crucial. Its forerunner, the Arpanet, was designed precisely to make place irrelevant, so that the destruction of one or more nodes would not affect its operation. If the emphasis on local community is as important as many stress (e.g., Felson, 1994), some means of making the Net responsive to local concerns seems important. Local communities are beginning to use it in this way, but $I$ remain ignorant of how the trend towards such use may best be fostered.

My own (probably fanciful) version of a world of self-selected environments, where you can, by choice, be exposed to nothing but sport, or nothing but paedophilic pornography. Your groceries are selected and delivered by someone who knows the pattern of your preferences and hence what new products to deliver. In such a world, genetics becomes ever more important, and criminal careers ever more specialised. I recall the heritability quotient of IQ 


\section{Ken Pease}

was greatest in nations with the best universal education, since this reduces the contribution of environmental determinants. Similarly, heritability of personality may increase insofar as the environment which reflects and extends original preferences becomes available.

It does not much matter if all the above options are overstated, distant in time, or just wrong. I suspect some are close. The increase in 'card not present' plastic fraud in the past year (John McVitie, APACS, personal communication) has to be linked to e-commerce. Given its rate of growth, the problems must be addressed as a matter of urgency.

The specifics of these suggestions may be discarded. However the underlying theme must be central to any dynamic crime reduction strategy. Unless policy begins to motivate crime reductive behaviour, the crime control enterprise is necessarily hobbled. Is this a challenge which Labour will seek to meet, or will it be subverted by the people processing preoccupations of the criminal justice process?

\section{Notes}

1 I am grateful to Inspector Tony Cross of the Metropolitan Police for educating me on the specifics of the technology.

2 While I have concentrated on situational examples, exactly the same points could be made about innovations from child care to prison training. I have chosen primarily examples of situational prevention because I believe them to be clearest and applicable in the short-term.

\section{References}

BenNahum, D. S. (1997) The internet revolution Wired 5.4, 122-73.

BRIdgeman, G. (1996) Crime Risk Management: Making Il Work. Crime Detection and Prevention Paper 70. London: Home Office.

BRoWNInG, J. (1997) Copyrighter's block Wired 5.5, 67-104.

Council OF EUROPE (1995) Crime and Economy. Strasbourg: Council of Europe.

CRADDOCK, A. (1997) Netwar and peace in the global village Wired 5.5, 52-226.

EквLом, P. (1986) The Prevention of Shop Theft: An Approach through Crime Analysis. Crime Prevention Paper 5. London: Home Office.

EквLом, P. (1997) Gearing up against crime: a dynamic framework to help designers keep up with the adaptive criminal in a changing world International Joumal of Risk, Security and Crime Prevention 2, 249-65.

Feison, M. (1994) Crime and Everyday Life. Thousand Oaks, California: Fine Forge Press.

FiELD, S. \& HOPE, T. (1990) Economics, the consumer and underprovision in crime prevention, in R. Morgan (ed.) Policing Organised Crime and Crime Prevention: British Criminology Conference 1989, Vol 4. Bristol: Bristol Centre for Criminal Justice.

GATES, B. (1995) The Road Ahead. New York: Viking.

Hope, T. (1995) Paper presented to the American Society of Criminology, Miami, October 1995 (unpublished).

Houghton, G. (1992) Car Theft in England and Wales: The Home Office Car Theft Index. Crime Prevention Unit Paper 33. London: Home Office.

Laycock, G. \& Tilley, N. (1995) Implementing crime prevention, in M. TonRy \& D. P. Farrington (eds) Building a Safer Society. Chicago: University of Chicago Press.

Lev, M., Bissell, P. \& Richardson, T. (1991). The Prevention of Cheque and Credit Card Fraud. Crime Prevention Paper 26. London: Home Office.

Maguire, M., Morgan, R. \& Reiner, R. (eds) (1997) The Oxford Handbook of Criminology (2nd edn). Oxford: Clarendon.

Matthews, R., Pease, C. \& Pease, K. (1998) Repeated bank robbery: theme and variations, in G. Farkell \& K. PEaSE (eds) Research in Repeal Victimisation. Monsey New York: Willow Tree Press (in press). 
Muraskin, R. \& Roberts, A. R. (eds) (1996) Visions for change: Crime and fustice in the Twenty-First Century. Upper Saddle River, New Jersey: Prentice-Hall.

Olander, J. D. \& Greenderg, H. (eds) (1977) Criminal Justice through Science Fiction. New York: Franklin-Watts.

OPP, K.-D. (ed.) (1986) Soft incentives and collective action: participation in the anti-nuclear movement British Foumal of Political Science 16, 87-112.

OPP, K.-D. (1989) The economics of crime and the sociology of deviant behaviour: a theoretical confrontation of basic propositions Kyklos 42, 405-30.

OPP, K.-D. (1994a) Repression and revolutionary action: East Germany in 1989 Rationality and Society 7, 101-38.

OPP, K.-D. (1994b) The role of voice in a future Europe Kyklos 47, 385-402.

PEASE, K. (1979) Some futures in crime prevention Research Bulletin 7. London: Home Office.

PIATT, C. (1997) Plotting away in Margaritaville Wired 5.7, 140-79.

RoberTs, N. D. (1996) Mobile Phone Crime. London: Home Office.

ScHWARTZ, E. I. (1997) It's not retail Wired 5.11, 218-94.

Sutton, M. \& MANN, R. (1998) Crime and the internet British Joumal of Criminology (in press).

WiLkins, L. T. (1973) Crime and criminal justice at the turn of the century Annals of the American Academy of Political and Social Science 408, 13-29. 